\title{
Effect of alternate furrow irrigation and potassium fertilizer on seed yield, water use efficiency and fatty acids of rapeseed
}

\author{
Efecto del riego deficitario y la fertilización potásica sobre la eficiencia en el uso \\ del agua, rendimiento y contenido de ácidos grasos en semillas de colza
}

\author{
Abdollah Bahrani ${ }^{1 *}$, Jafar Pourreza ${ }^{1}$
}

\begin{abstract}
In order to study the effect of restricted irrigation systems and different amounts of potassium fertilizer on water use efficiency and yield of rapeseed (Brassica napus L.), an experiment was conducted in an arid area in Khuzestan, Iran in 2013. The main plots consisted of three irrigation methods: FI (full irrigation), alternate furrow irrigation (AFI) and fixed furrow irrigation (FFI), Each subplot received three rates of $\mathrm{K}$ fertiliser application: 0,150 or $300 \mathrm{~kg} \mathrm{ha}^{-1}$. The results showed that the plots receiving full irrigation produced significantly higher grain yield, 1000-kernel weight and grain number per pod than both alternate treatments. However, the highest WUE was obtained with alternate furrow irrigation and $300 \mathrm{~kg} \mathrm{~K} \mathrm{ha}^{-1}$ and the lowest was found in the FI treatment and $0 \mathrm{~kg} \mathrm{~K} \mathrm{ha}^{-1}$. Potassium application increased RWC in alternate furrow irrigation and fixed furrow irrigation more than the FI treatment. Maximum oil content was observed in those treatments where full irrigation was applied while minimum oil content was produced in FFI irrigated treatments. Potassium fertilizer also increased grain oil by $15 \%$ over the control. Deficit irrigation reduced oleic acid and erucic acid; however oleic acid and linoleic acid increased with increasing potassium.
\end{abstract}

Key words: erucic acid, irrigation methods, linoleic acid, oil percent, oleic acid.

\section{RESUMEN}

El experimento se realizó en una zona árida en Khuzestan, Irán durante 2013, con el objetivo de estudiar el efecto del riego deficitario y diferentes dosis de fertilización potásica sobre la eficiencia en el uso del agua y el rendimiento de semilla de colza (Brassica napus L.). Los experimentos fueron tres parcelas regadas con tres métodos de riego: riego completo (FI), riego por surco alterno (AFI) y riego por surco fijo (FFI). En cada parcela se fertilizó con tres dosis potasio: 0,150 o $300 \mathrm{~kg} \mathrm{ha}^{-1}$. Los resultados sugieren que las parcelas que recibieron riego completo obtuvieron significativamente mayor rendimiento de grano, peso de 1000 granos y número de granos por vaina que los tratamientos alternativos. La mayor eficiencia en el uso del agua se obtuvo en riego por surcos alternos y $300 \mathrm{~kg}$ de $\mathrm{K} \mathrm{ha}^{-1}$ y la menor eficiencia se encontró en el tratamiento FI y $0 \mathrm{~kg}$ de $\mathrm{K} \mathrm{ha}^{-1}$. El mayor contenido de aceite se obtuvo en aquellos tratamientos donde se aplicó riego completo mientras que el menor contenido se obtuvo en FFI. La fertilización potásica aumentó el contenido de aceite en el grano en un 15\% sobre el control. El riego deficitario reduce el ácido oleico y ácido erúcico; sin embargo, el ácido oleico y el ácido linoleico aumentó con el aumento de potasio.

Palabras clave: ácido erúcico, métodos de riego, ácido linoleico, porcentaje de aceite, ácido oleico.

\section{Introduction}

Rape seed (Brassica napus L.) is an important oil crop, ranking third only to soybean and palm oil in global production (Muhammad et al., 2007). World area under rape seed was 33.78 million ha with a grain production of 62.69 million tonnes and overall yield of $1856 \mathrm{~kg}$ per hectare during 2010-2011. In Iran rapeseed was grown on 165 thousand hectares with annual production of 345 thousand tonnes and average yield of $2090 \mathrm{~kg}$ per ha (FAO 2011).

Innovations for saving water in irrigated agriculture and thereby improving water use efficiency are of paramount importance in waterscarce regions. Conventional deficit irrigation (DI) is one approach that can reduce water use without causing significant yield reduction (Kirda et al., 2005). Alternative furrow irrigation is a further development of DI. Alternative furrow irrigation

\footnotetext{
1 Department of Agriculture, Ramhormoz Branch, Islamic Azad University, Ramhormoz, Iran.

* Corresponding author: abahrani@iauramhormoz.ac.ir, abahrani75@yahoo.com
}

Fecha de Recepción: 21 Enero, 2016.

Fecha de Aceptación: 22 Febrero, 2016. 
is commonly applied as part of a deficit irrigation program because it does not require the application of more than $50-70 \%$ of the water used in a fully irrigated program (Marshal et al., 2008). Alternate furrow irrigation was proposed as a method to increase water use efficiency and decrease chemical leaching compared to every-furrow irrigation and with small yield losses for different crops compared to a fixed furrow irrigation system (Shaheed Siddiqui et al., 2008; Abedi and Pakniyat 2010). It appears that placing fertilizer in the non-irrigated furrow of an alternate furrow irrigation system or in the row with either alternate or every furrow irrigation has the potential to decrease fertilizer leaching and nutrient element poisoning without reducing crop productivity (Kassam et al., 2007). In maize alternative furrow irrigation reduced water consumption by $35 \%$ with a total biomass reduction of $6-11 \%$ compared to fully watered plants (Bahrani et al., 2012).

Iran faces a serious problem of water shortage for crop production. Water resources are becoming limiting and it has been estimated that water for irrigation purposes may be reduced up to $50 \%$ (Cakmak 2005). Therefore, the objective of this study was to examine the effects of alternate furrow irrigation strategies and the role of potassium application on grain yield and water use efficiency of the rape seed crop under the Mediterranean climatic conditions in southern Iran.

\section{Materials and Methods}

A field experiment with the hybrid rape seed variety Hayola 401 was conducted in an arid area in western Iran, at the Islamic Azad University of Ramhormoz, Khuzestan, Iran ( $31^{\circ} 16^{\prime}$ N , 49 $36^{\prime}$ E and $150.5 \mathrm{~m}$ above sea level) during 2013-2014. Some metrological data of the experimental location is shown in Table 1. A split-plot experimental design was used, based on a complete randomised block design with three replications. The main plots consisted of three irrigation methods: FI (full irrigation) was the conventional way where every furrow was irrigated during each watering cycle with $100 \%$ of the water typically applied to the crop in Khuzestan according to crop requirements, AFI (alternate furrow irrigation) and FFI (fixed furrow irrigation). Each subplot received three rates of $\mathrm{K}$ (in the form of potassium sulphate) fertiliser application: 0,150 or $300 \mathrm{~kg} /$ ha. Irrigation treatments were applied 30 days after planting. $\mathrm{N}$ and $\mathrm{P}$ fertilizer were applied according to recommendations of soil testing in forms of urea and superphosphates, respectively. Plots were sown on 3 November 2013 with a four row planting machine, and were $8 \mathrm{~m}$ long and $4 \mathrm{~m}$ wide, with 8 rows $0.50 \mathrm{~m}$ apart. Plots were ploughed and disked after winter wheat harvest in June. During the growth period all plots were weeded manually. No serious incidence of insects or disease was observed and no pesticide or fungicide was applied. A drip irrigation system was used in the study. The soil water content measurements were done one day before irrigation until harvest in three replications for all treatments by gravimetric sampling in $0-0.30 \mathrm{~m}$.

\section{Water use efficiency (WUE)}

WUE was computed as the ratio of canola grain yield to seasonal water use. To determine total dry matter above ground level, five plants within 0.5-0.6 $\mathrm{m}$ of a row section in each plot were cut at ground level at maturity stage. Plant samples were dried at $65{ }^{\circ} \mathrm{C}$ until constant weight. Rape seed grain yields were determined by hand harvesting the 6 $\mathrm{m}$ sections of five centre rows in each plot on April 21,2014 . Then grain yield values were adjusted to $15.5 \%$ moisture content. In addition, 1000-kernel weight and harvest index values were also evaluated.

Table 1. Metrological statistics in the experimental location during the experiment.

\begin{tabular}{lcccccc}
\hline $\begin{array}{c}\text { Months of } \\
\text { Experiment }\end{array}$ & $\begin{array}{c}\text { Average } \\
\text { minimum } \\
\text { temperature }{ }^{\circ} \mathrm{C}\end{array}$ & $\begin{array}{c}\text { Average } \\
\text { maximum } \\
\text { temperature }{ }^{\circ} \mathrm{C}\end{array}$ & $\begin{array}{c}\text { Average } \\
\text { minimum relative } \\
\text { humidity }(\%)\end{array}$ & $\begin{array}{c}\text { Average } \\
\text { maximum relative } \\
\text { humidity (\%) }\end{array}$ & $\begin{array}{c}\text { Evaporation } \\
\text { from Class } \\
\text { A pan }(\mathrm{mm})\end{array}$ & $\begin{array}{c}\text { Rainfall } \\
(\mathrm{mm})\end{array}$ \\
\hline November & 15.0 & 29.7 & 16 & 42 & 70.9 & 14.0 \\
December & 9.8 & 24.1 & 22 & 53 & 67.8 & 10.0 \\
January & 10.1 & 20.5 & 48 & 77 & 64.6 & 44.2 \\
February & 12.2 & 22.6 & 38 & 56 & 54.3 & 30.0 \\
March & 15.5 & 29.0 & 25 & 52 & 113.4 & 12.6 \\
April & 20.2 & 33.4 & 20 & & 136.1 & 36.1 \\
\hline
\end{tabular}




\section{Relative water content}

Leaf tissue was used for relative water content (RWC) determination, as follows: A composite sample of leaf discs of four leaves of similar physiological maturity is taken and the fresh weight is determined, followed by flotation on water for up to $4 \mathrm{~h}$ under normal room light and temperature. The turgid weight is then recorded, and the leaf tissue is subsequently oven-dried to constant weight at about $85^{\circ} \mathrm{C}$. RWC was calculated according to Aliabadi et al., (2008).

$$
\operatorname{RWC}(\%)=\frac{(\mathrm{FP}-\mathrm{DW})}{(\mathrm{TW}-\mathrm{SW})} \times 100
$$

Where, FW is fresh weight, DW dry weight and TW turgid weight.

\section{Oil seed content}

The oil concentration of a sample of whole seeds from each plot was determined by nearinfrared reflectance spectroscopy as described by Bhatty (1991).

\section{Fatty acids}

Fatty acids were esterified as methyl esters (AOAC 1990) and analysed by Agilent 6890 N GC equipped with a DB-23 capillary column (60 $\mathrm{m} \mathrm{x}$ $0.25 \mu \mathrm{m})$ and an FID (Flame Ionization Detector). The carrier gas was helium, at a flow rate of $1.2 \mathrm{~mL} /$ $\mathrm{min}$. Both injector and detector temperatures were kept at $250^{\circ} \mathrm{C}$. Column temperature was initially kept at $165^{\circ} \mathrm{C}$ for $15 \mathrm{~min}$ and then increased to 200 ${ }^{\circ} \mathrm{C}$ at a rate of $5{ }^{\circ} \mathrm{C} / \mathrm{min}$, where it was maintained for $15 \mathrm{~min}$. Samples of $1 \mu \mathrm{l}$ were injected by autosampler, in the split mode (1:50). The fatty acid identification was performed by retention time comparisons with corresponding fatty acid methyl ester standards. The standards were purchased from Sigma-Aldrich Ltd.

\section{Statistical analysis}

Data were analysed by ANOVA using the general linear model (GLM) procedure provided by SAS (2004). When significant differences were found $(p=0.05)$, Duncan's multiple range test (DMRT) was carried out.

\section{Results and Discussion}

\section{Yield and yield components}

Analysis of variance of the grain yield data indicated that irrigation treatments significantly affected yields $(p<0.05)$. The plots receiving full irrigation (FI) resulted in significantly higher grain yields than both irrigation treatments (Table 2 and 3). Grain yields varied from 1478 to $1832 \mathrm{~kg} / \mathrm{ha}$ among the treatments. The highest average grain yield $(1832 \mathrm{~kg} / \mathrm{ha}$ ) was observed in the FI treatment, and the lowest yield $(1478 \mathrm{~kg} / \mathrm{ha})$ was found in fixed furrow irrigation treatment when irrigation was reduced by $50 \%$. Alternate and fixed furrow irrigation treatments resulted in significantly $(p<$ 0.05 ) lower grain yield (20 and $25 \%$, respectively) compared to the FI treatment. Yield in fixed furrow irrigation treatment was 5\% lower than alternate furrow irrigation treatment. Jianweil et al., (2007), showed that rapeseed grain yield was significantly

Table 2. Mean values of the traits under three irrigation methods and potassium fertilizer.

\begin{tabular}{|c|c|c|c|c|c|c|c|}
\hline Treatments & $\begin{array}{c}\text { 1000-Kernel } \\
\text { weight }(\mathrm{g})\end{array}$ & $\begin{array}{c}\text { Grain Yield } \\
\mathrm{Kg} / \mathrm{ha}\end{array}$ & $\begin{array}{c}\text { WUE }+ \\
\text { Kg grain/m }\end{array}$ & Oil percent & Oleic Acid & Linoleic Acid & Erucic Acid \\
\hline \multicolumn{8}{|l|}{ Irrigation } \\
\hline FI & $3.36 \mathrm{a}$ & $1832 \mathrm{a}$ & $0.3 \mathrm{~b}$ & $45.2 \mathrm{a}$ & $63.24 \mathrm{a}$ & $20.24 \mathrm{a}$ & $0.193 \mathrm{a}$ \\
\hline $\mathrm{AFI}^{*}$ & $2.95 \mathrm{a}$ & $1524 \mathrm{~b}$ & $0.75 \mathrm{a}$ & $39.8 \mathrm{~b}$ & $65.31 \mathrm{~b}$ & $16.91 \mathrm{~b}$ & $0.327 \mathrm{~b}$ \\
\hline $\mathrm{FFI} \leftrightarrow$ & $1.91 \mathrm{~b}$ & $1478 \mathrm{~b}$ & $0.80 \mathrm{a}$ & $38.6 \mathrm{~b}$ & $66.42 \mathrm{~b}$ & $17.52 \mathrm{~b}$ & $0.426 \mathrm{~b}$ \\
\hline \multicolumn{8}{|c|}{ Potassium fertilizer } \\
\hline 0 & $2.83 \mathrm{~b}$ & $1150 \mathrm{~b}$ & $0.45 \mathrm{c}$ & $36.6 \mathrm{~b}$ & $59.11 \mathrm{~b}$ & $21.9 \mathrm{~b}$ & $0.320 \mathrm{a}$ \\
\hline 150 & $3.17 \mathrm{a}$ & $1510 a b$ & $0.86 \mathrm{~b}$ & $41.9 \mathrm{a}$ & $61.52 \mathrm{a}$ & $22.12 \mathrm{a}$ & $0.304 \mathrm{~b}$ \\
\hline 300 & $3.30 \mathrm{a}$ & $1860 \mathrm{a}$ & $1.04 \mathrm{a}$ & $42.1 \mathrm{a}$ & $61.21 \mathrm{a}$ & $22.19 \mathrm{a}$ & $0.307 \mathrm{~b}$ \\
\hline
\end{tabular}

* Alternate furrow irrigation, $\$$ Fixed furrow irrigation, $¥$ Water use efficiency.

Same letters in a column are not significantly different at $\mathrm{p} \leq 0.05$. 
Table 3. Mean values of the traits as affected by irrigation and potassium fertilizer.

\begin{tabular}{|c|c|c|c|c|c|c|c|c|}
\hline & Treatments & $\begin{array}{c}\text { 1000-Kernel } \\
\text { weight(g) }\end{array}$ & $\begin{array}{c}\text { Grain Yield } \\
\mathrm{Kg} / \mathrm{ha}\end{array}$ & $\begin{array}{c}\text { WUE } \$ \\
\text { Kg grain/m }\end{array}$ & $\begin{array}{c}\text { Oil } \\
\text { percent }\end{array}$ & $\begin{array}{l}\text { Oleic } \\
\text { Acid }\end{array}$ & $\begin{array}{l}\text { Linoleic } \\
\text { Acid }\end{array}$ & $\begin{array}{c}\text { Erucic } \\
\text { Acid }\end{array}$ \\
\hline \multirow[t]{2}{*}{ Irrigation } & Potassium fertilizer & & & & & & & \\
\hline & 0 & 3.09 & 1491 & 40.9 & 61.17 & 21.07 & 0.256 & 22 \\
\hline \multirow[t]{3}{*}{ FI } & 150 & 3.26 & 1632 & 43.5 & 62.38 & 21.18 & 0.248 & 24 \\
\hline & 300 & 3.33 & 1710 & 43.6 & 62.22 & 21.21 & 0.250 & 25 \\
\hline & 0 & 2.89 & 1337 & 38.2 & 62.21 & 19.40 & 0.323 & 21 \\
\hline \multirow[t]{3}{*}{$\mathrm{AFI}^{*}$} & 150 & 3.06 & 1517 & 40.8 & 63.41 & 19.51 & 0.315 & 22 \\
\hline & 300 & 3.12 & 1692 & 40.9 & 63.26 & 19.55 & 0.317 & 24 \\
\hline & 0 & 2.37 & 1314 & 37.6 & 62.76 & 19.71 & 0.373 & 22 \\
\hline \multirow[t]{2}{*}{$\mathrm{FFI} \stackrel{+}{\sharp}$} & 150 & 2.54 & 1494 & 40.2 & 63.97 & 19.82 & 0.365 & 23 \\
\hline & 300 & 2.60 & 1669 & 40.3 & 63.81 & 19.85 & 0.366 & 25 \\
\hline \multirow{5}{*}{$\begin{array}{c}\text { LSD }(0.05) \\
\text { S.O.V }\end{array}$} & & 0.7 & 356 & 2.23 & 5.1 & 4.2 & 0.02 & 7.5 \\
\hline & Irrigation (I) & $*$ & $*$ & $*$ & $*$ & $* *$ & $* *$ & $*$ \\
\hline & Potassium fertilizer $(\mathrm{P})$ & $*$ & $*$ & $*$ & $*$ & $*$ & $*$ & $*$ \\
\hline & $\mathrm{I} \times \mathrm{P}$ & $*$ & $*$ & $*$ & $\mathrm{~ns}$ & $\mathrm{~ns}$ & ns & $\mathrm{ns}$ \\
\hline & $\mathrm{CV}(\%)$ & 5.59 & 19.45 & 21.22 & 18.71 & 18.71 & 18.71 & 17.36 \\
\hline
\end{tabular}

$*$ Alternate furrow irrigation, $\$$ Fixed furrow irrigatiWon, $\ddagger$ Water use efficiency.

$*, * *$ Significant at 0.05 and 0.01 probability levels, respectively. Same letters in a column are not significantly different at $\mathrm{p} \leq 0.05$.

affected by potassium application; they observed significant increases of about 17.5 and $31.7 \%$ using 150 and $300 \mathrm{~kg} / \mathrm{ha} \mathrm{K}_{2} \mathrm{O}$, respectively, compared to the control.

The highest and lowest grain yields in consumption were $1760 \mathrm{~kg} / \mathrm{ha}$ with $300 \mathrm{~kg} \mathrm{~K} / \mathrm{ha}$ and $1150 \mathrm{~kg} / \mathrm{ha}$ in the control. Potassium fertilizer increased grain yield by $65 \%$ and $31 \%$, respectively, compared to the control (Figure 1). Potassium fertilizer application in deficit irrigation treatments increased grain yield more than in the full irrigation treatment. In the full irrigation treatment at the highest potassium fertilizer treatment grain yield increased $15 \%$; however, at the same potassium level grain yield increased by $26 \%$ in the alternate furrow irrigation treatment (Table 3).These results are

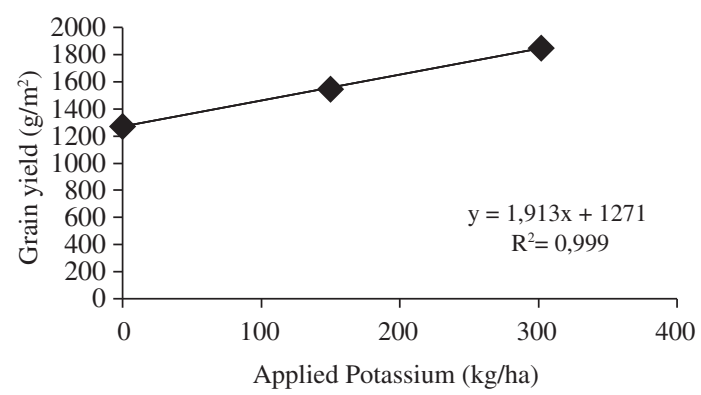

Figure 1. Mean grain yield response of canola to potassium fertilizer. similar to those found by Fanaei et al., (2009), that with increasing stress grain yield reduced severely, except with $\mathrm{K}^{+}$application that produced a huge increase in rapeseed yield. It is clear that $\mathrm{K}^{+}$levels could ameliorate the negative effects of water stress on seed yield and physiological indicators and as a result improve them (Fanaei et al., 2009).

In this study there were significant differences in 1000-kernel weight among different irrigation treatments. The highest 1000-kernel weight was observed in the FI treatment, $3.36 \mathrm{~g}$, and the lowest was the FFI treatment, $1.91 \mathrm{~g}$. Deficit irrigation reduced 1000-kernel weight; however, there was no significant difference between AFI and FFI treatments. Deficit irrigation decreases the effective filling period of seed, but it does not affect the collection of dry material in the endosperm and the germ (Wasson et al., 2002). Kamkar et al., (2011) observed a reduction in 1000 grain weight under drought stress conditions. Moreover, the reduction in the production and translocation of photosynthates to the developing seed might cause loss in grain weight.

The results showed significant differences among different potassium fertilizer levels on 1000-kernel weight. The highest 1000-kernel weight was obtained with consumption rate of potassium of $300 \mathrm{~kg} / \mathrm{ha}$ and the lowest was in the control. This indicates that 1000 -kernel weight increased by $21 \%$ with 
consumption of $300 \mathrm{~kg} / \mathrm{ha}$ relative to the control (Table 2). However, the difference between 150 and $300 \mathrm{~kg} \mathrm{~K} / \mathrm{ha}$ was not significant.

\section{Water use efficiency}

The highest water use efficiency (WUE), averaging $0.8 \mathrm{~kg} / \mathrm{m}^{3}$, was obtained in the AFI treatment, followed by AFI with $0.75 \mathrm{~kg} / \mathrm{m}^{3}$; the lowest was found in the FI treatment, $0.3 \mathrm{~kg} / \mathrm{m}^{3}$ (Table 2). Kang and Zhang (2004) reported that water use as percent of fully irrigated treatment is decreased and irrigation water use efficiency (IWUE) is increased by alternate furrow irrigation as reported in a number of species, e.g. cotton, tomato, pear, grapevine and hot pepper. The highest water use efficiency, averaging $1.04 \mathrm{~kg} / \mathrm{m}^{3}$, was obtained with $300 \mathrm{~kg} \mathrm{~K} \mathrm{ha}^{-1}$ and the lowest with the $0 \mathrm{~kg} \mathrm{~K} / \mathrm{ha}$ treatment, $0.45 \mathrm{~kg} / \mathrm{m}^{3}$ (Tables 2 and 3). Potassium regulates stoma closure and prevents water wasting, and by regulating osmosis, increases WUE and improves growth in corn (Wiebold and Scharf, 2006), while potassium consumption tends to accelerate canopy formation and cause more water to be available for use by plants and even plant early maturation (Cakmak 2005). Soil nutrients such as potassium ions affect water transport in the whole plant, maintain cell pressure and regulate the opening and closing of stomata (Wortmann et al., 2009, Parsons et al., 2007).

\section{Relative water content (RWC)}

RWC was significantly lower in water-stressed plants than in plants grown under normal conditions. Application of K improved RWC under both moisture levels with greater effect at K300. The higher K

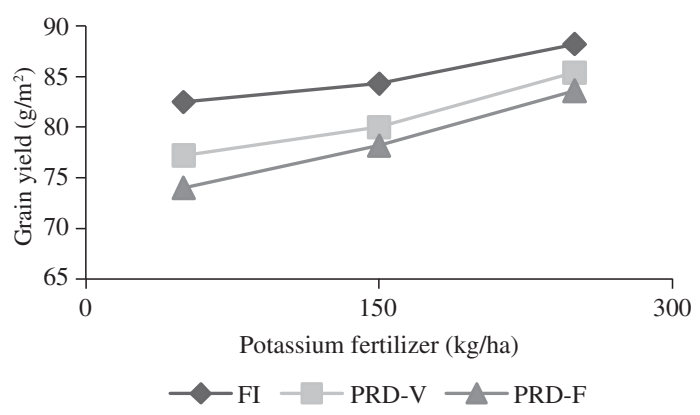

Figure 2. Relative water content of leaf as afected by potassium fertilizer and irrigation methods. application increased RWC by $10 \%$ under normal conditions, and by $12 \%$ and $16 \%$ under FFI and AFI, respectively (Figure 2). Mengel and Kirkby (2001) observed that due to low K concentration, ROS production was induced during water deficit which caused disturbance in stomata opening. Fusheng (2006) revealed that lower water loss of plants well supplied with $\mathrm{K}+$ is due to a reduction in transpiration which not only depends on the osmotic potential of mesophyll cells but also is controlled to a large extent by opening and closing of stomata.

\section{Oil content}

Both irrigation methods and potassium fertilizer had a significant effect on grain oil percent (Table 2 and 3). Irrigation methods had a strong significant $(\mathrm{P}<0.05)$ effect on oil content of rapeseed. The results revealed that maximum oil content of $45.2 \%$ was observed in those treatments where full irrigation was applied, while minimum oil content (38.6\%) was produced in FFI irrigated treatments. According to Bouchereau et al., (1996) decrease in oil concentration in rapeseed grain exposed to water deficit is justified by changes in availability of precursors to fill the grain, as reproductive organs and grains are built of resources either recently acquired or previously amassed in the vegetative part. Potassium fertilizer also increased grain oil by $15 \%$ over control. However, there was no significant difference between 150 and $300 \mathrm{~kg} \mathrm{~K} / \mathrm{ha}$.

\section{Fatty acids}

There were significant differences in irrigation methods in these traits (Table 2). The lowest oleic acid and erucic acid were observed in the FI treatment, $63.24 \%$ and $0.193 \%$, respectively and the highest were found in the FFI treatment, $66.42 \%$ and $0.426 \%$. Deficit irrigation reduced oleic acid and erucic acid; however, there was no significant difference between AFI and FFI treatments. Inversely, the highest linoleic acid was found in the FI treatment, $20.24 \%$, and the lowest in FFI, $17.52 \%$.

Oleic acid and linoleic acid also increased with addition of potassium, and produced the highest content at the rate of $150 \mathrm{~kg} / \mathrm{ha}$. Application of more than $150 \mathrm{~kg} / \mathrm{ha}$ of potassium decreased these two traits. However, erucic acid decreased with increasing potassium application. The correlation coefficients between traits showed that grain yield 
had a positive and significant correlation with oil yield and biological yield $(\mathrm{p}<0.01)$; oil yield also had positive correlation with oil percent. Negative correlation was observed between number of seeds per pod and 1000-kernel weight (Table 4).

\section{Conclusions}

Deficit irrigation techniques (AFI and FFI) reduced rapeseed yields by 20 and $25 \%$ compared to FI irrigation. The AFI and FFI irrigation strategies were equally effective in saving irrigation water. Alternate furrow irrigation practice for rapeseed provides water use efficiency benefit compared to full irrigation (FI). The value of benefits from water saving should be balanced with the value of yield reductions and the cost of implementing alternative irrigation system compared to conventional systems.

Potassium fertilizer application in deficit irrigation treatments increased grain yield more than full irrigation treatment. 1000-kernel weight and biological yield were increased with consumption of $300 \mathrm{~kg} \mathrm{~K} / \mathrm{ha}$ relative to the control. However, there were no significant differences between 150 and $300 \mathrm{~kg} \mathrm{~K} / \mathrm{ha}$. Potassium fertilizer improved RWC under three moisture levels with the maximum effect at K300.

\section{Acknowledgments}

Funds for this research was provided by the Islamic Azad University of Ramhormoz, Khuzestan, Iran.

Table 4. Simple correlation coefficients between traits.

\begin{tabular}{|c|c|c|c|c|c|c|c|}
\hline Factor & 1 & 2 & 3 & 4 & 5 & 6 & 7 \\
\hline \multicolumn{8}{|l|}{ 1- Number of pods per plant } \\
\hline 2- Number of seeds per pod & -0.023 & & & & & & \\
\hline 3-1000-kernel weight & -0.05 & $-0.746^{* *}$ & & & & & \\
\hline 4- Biological yield & 0.477 & 0.078 & 0.172 & & & & \\
\hline 5- Grain yield & 0.581 & 0.203 & 0.082 & $0.81 * *$ & & & \\
\hline 6- Oil percent & -0.064 & -0.087 & 0.084 & 0.164 & 0.102 & & \\
\hline 7- Harvest Index & 0.521 & 0.01 & 0.079 & 0.015 & 0.58 & -0.073 & \\
\hline 8- Oil yield & 0.484 & 0.171 & 0.19 & 0.238 & $0.884 * *$ & $0.637 *$ & 0.029 \\
\hline
\end{tabular}

\section{Literature Cited}

Abedi, T.; Pakniyat, $\mathrm{H}$.

2010. Antioxidant enzyme changes in response to drought stress in ten cultivars of oilseed rape Brassica napus L. Czech J. Genetics Plant Breed., 46: 27-34.

Aliabadi, F.H.; Lebaschi, M.H.; Shiranirad, A.H.; Valadabadi, S.A.R.; Daneshian, J.

2008. Effects of arbuscular mycorrhizal fungi, different levels of phosphorus and drought stress on water use efficiency, relative water content and proline accumulation rate of Coriander (Coriandrum sativum L.). J. Medical Plants Res., 2 (6): 125-131.

AOAC.

1990. Official Methods of Analysis. 15th Ed,Association of Analytical Chemists. Arlington, Virginia, USA. 1298 p.

Bahrani, A.; Pourreza, J.; Madani, A.; Amiri, F.

2012. Effect of PRD irrigation method and potassium fertilizer application on corn yield and water use efficiency. Bulgarian J. Agric. Sci., 18: 616-625.

Bhatty, R.S.

1991. Measurement of oil in whole flaxseed by near infrared reflectance spectroscopy. Journal American Oil Chemistry Society, 68: 34-38.
Bouchereau, A.; Clossais-Besnard, N.; Bensaoud, A.; Leport, L.; Renard, M.

1996. Water stress effects on rapeseed quality. European $J$. Agron., 5 (1): 19-30.

Cakmak, I.

2005. The role of potassium in alleviating detrimental effects of abiotic stresses in plants. Plant Nutrition Soil Sci., 168: 521-530.

Fanaei, H.R.; Galavi, M.; Kafi, M.B.; Onjar, A.G.

2009. Amelioration of water stress by potassium fertilizer in two oilseed species. Int. J. Plant Production, 3: 41-54.

F.A.O. Production Year Book.

2011. Food and Agriculture Organization of United Nation, Rome, Italy. 51: 209P.

Fusheing, L.

2006. Potassium and water interaction. International workshop on soil potassium and $\mathrm{k}$ fertilizer management. Agricultural College Guangxi University 1-32.

Jianwei, L.; Zou, J.M.; Chen, F.

2007. Effect of phosphorus and potassium application on rapeseed yield and nutrients use efficiency. Proceedings of 
the ${ }^{12}$ th International Rapeseed Congress. Wuhan, China. 202-205.

Kamkar, B.; Daneshmand, A.R.; Ghooshchi, F.; Shiranirad, A.H.; Langeroudi, A.R.S.

2011. The effects of irrigation regimes and nitrogen rates on some agronomic traits of canola under a semi-arid environment. Agric. Water Management., 98: 1005-1012.

Kang, S.Z.; Zhang, J.

2004. Controlled alternate partial root-zone irrigation: its physiological consequences and impact on water use efficiency. J. Exp. Botany., 55 (407): 2437-2446.

Kassam, A.H.; Molden, D.; Fereres, E.; Doorenbos, J. 2007. Water productivity: science and practice introduction. Irrigation Sci., 25: 185-188.

Kirda, C.; Topcu, S.; Kaman, H.; Ulger, A.C.; Yazici, A.; Cetin, M.; Derici, M.R.

2005. Grain yield response and $\mathrm{N}$-fertilizer recovery of maize under deficit irrigation. Field Crops Res., 93: 132-141.

Marshal, J.; Mata, M.; del Campo, J.; Arbones, A.; Vallverdú, X.; Girona, J.; Olivo, N.

2008. Evaluation of partial root-zone drying for potential field use as a deficit irrigation technique in commercial vineyards according to two different pipeline layouts. Irrigation Sci., 26: 347-356.

Mengel, K.; Kirkby, E.A.

2001. Principles of plant nutrition. ${ }^{5}$ th ed., Kluwer Academic Publishers, Dordrecht. 849 pp.
Muhammad, N.; Cheema, M.A.; Wahid, M.A.; Ahmad, N.; Zaman, M.

2007. Effect of source and method of nitrogen fertilizer application on seed yield and quality of canola (Brassica napus L.). Pakistanian J. Agric. Sci., 44 (1): 74-78.

Parsons, K.J., Zheljazkov, V.D.; MacLeod, J.; Caldwell, C.D. 2007. Soil and tissue phosphorus, potassium, calcium and sulfur as affected by dairy manure application in a no-till corn, wheat and soybean rotation. Agron. J., 99: 1306-1316. SAS Institute, Inc.

2004. SAS/STAT 9.1 User'sguide. SAS Institute Inc., Cary, NC.

Shaheed Siddiqui, Z.; Ajmal Khan, M.; Kim, B.G.I.; Huang, J.S.; Kwon T.

2008. Physiological responses of Brassica napus genotypes to combined drought and salt stress. Plant Stress., 2: 78-83.

Wasson, J.J.; Schumacher, R.; Wicks, T.E.

2002. Maize water content and solute potential at three stages of development. Maydica, 45 (1): 67-72.

Wiebold, B.; Scharf, P.

2006. Potassium deficiency symptoms in drought stressed crops, plant stress resistance and the impact of potassium application south china. Agron. J., 98: 1354-1359.

Wortmann, C.A.; Dobermann, A.R.; Ferguson, R.B.; Hergert, G.W.; Shapiro, C.A.; Tarkalson, D.D.; Walters, D.T.

2009. High-yielding corn response to applied phosphorus, potassium, and sulfur in Nebraska. Agron. J., 101: 546-555. 
